Metal-Catalyzed Asymmetric Synthesis and Stereoselective

Reactions

\title{
Gold-Catalyzed Enantioselective Protonation
}<smiles>COc1ccccc1[Tl]</smiles>

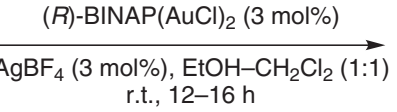<smiles>CCCC(=O)c1ccccc1[Te]</smiles>

$\mathrm{R}^{1}, \mathrm{R}^{2}, \mathrm{R}^{3}=$ Alk, $\mathrm{Ar}$ $\mathrm{n}=0,1,2$

$E / Z$ acyclic substrate from $1: 1$ to $5: 1$

$82-98 \%$ yield

$82-95 \%$ ee

$0.1 \mathrm{mmol}$ scale

Selected examples:<smiles>CC1CCc2ccccc2C1=O</smiles>

1

$96 \%$ yield 93\% ee<smiles>CC(C(=O)c1ccccc1)c1ccc(C(F)(F)F)cc1</smiles>

2

$E / Z^{a}=1: 1$

$92 \%$ yield

$92 \%$ ee<smiles>C[C@H](C(=O)c1ccccc1)c1ccccc1</smiles>

3

$E / Z=2: 1,97 \%$ yield, $92 \%$ ee $E / Z=3: 1,96 \%$ yield, $90 \%$ ee

a refers to $E / Z$ ratio of substrate

Significance: The catalytic enantioselective protonation of silyl enol ethers was realized via a cationic gold-activated Brønsted acid. While enantioselective protonations of cyclic silyl enol ethers of ketones are known (see Review below), no prior precedents on Brønsted acid catalyzed protonation existed for the acyclic variants.

Review: J. T. Mohr, A. Y. Hong, B. M. Stoltz Nat. Chem. 2009, 1, 359-369.
Comment: The cationic gold $(I)$ is proposed to complex with the alcohol and acidify the hydroxyl proton forming a Brønsted acid. The possibility of $\mathrm{AgBF}_{4} \cdot$ BINAP-mediated protonation was ruled out as the silver complex was unreactive. However, excellent yields and ee values were achieved regardless of the $E / Z$ ratio of the silyl enol ethers 2 and 3. Mechanistic investigations suggest that the catalyst approaches the substrate from the same prochiral face with respect to each geometric isomer.
Key words

cationic gold

enantioselective protonation

silyl enol ethers

SYNFACThen of the cing 